\title{
Effect of myo-inositol supplementation on the development of renal pathological changes in the Cohen diabetic (type 2) rat
}

\author{
A.M. Cohen ${ }^{1}$, H. Wald ${ }^{2}$, M. Popovtzer ${ }^{2}$, E. Rosenmann ${ }^{1}$ \\ ${ }^{1}$ Department of Pathology, Hadassah Hebrew University Hospital, Jerusalem, Israel \\ ${ }^{2}$ Nephrology Services, Hadassah Hebrew University Hospital, Jerusalem, Israel
}

\begin{abstract}
Summary A lower concentration of intracellular myo-inositol has been implicated in the development of diabetic nephropathy. This was based on short-term studies showing that early administration of aldose reductase inhibitors or myo-inositol supplementation reduces increased glomerular filtration rate and partly reduces increased urinary albumin excretion in streptozotocin diabetic rats. We studied the effect of long-term (4 months) administration of $1 \%$ myo-inositol supplement to the Cohen diabetic (type 2) rat on the development of nephropathy and renal $\mathrm{Na}^{+}-\mathrm{K}^{+}$-ATPase. This treatment reduced the increased renal $\mathrm{Na}^{+}-\mathrm{K}^{+}$-ATPase activity but had no effect on blood glucose levels, body weight, increased kidney weight, or creatinine clearance and did not prevent or reduce the development of renal glomerular pathology. There was no correlation between the level of $\mathrm{Na}^{+}-\mathrm{K}^{+}-$
\end{abstract}

ATPase activity and the degree of nephropathy. It is possible that the renal pathological changes are due to metabolic and humoral factors resulting from hyperglycaemia, other than myo-inositol depletion. The fact that myo-inositol treatment had no effect on the development of renal pathological changes but was shown to have a beneficial effect on restoring impaired conduction velocity and on the disruption of structural elements in the nerve indicates that the effect of the biological changes ensuing from hyperglycaemia vary in different tissues depending on local conditions. [Diabetologia (1995) 38: 899-905]

Key words Non-insulin-dependent diabetes mellitus (type 2), myo-inositol, glomerulosclerosis, $\mathrm{Na}^{+}-\mathrm{K}^{+}-$ ATPase, Cohen-diabetic rat.
It has been suggested that polyol pathway hyperactivity contributes to the pathogenesis of diabetic renal complications [1-4]. This was based on the observation that treatment with aldose reductase inhibitors and myo-inositol supplements reduces the increased glomerular filtration rate $[5,6]$ and partly reduces in-

Received: 25 April 1994 and in final revised form: 14 February 1995

Corresponding author: Professor A. M. Cohen, Department of Pathology, Hadassah University Hospital, POB 12000, Jerusalem 91210, Israel

Abbreviations: Pi, Inorganic phosphate; IDDM, insulin-dependent diabetes mellitus; NIDDM, non-insulin-dependent diabetes mellitus; STZ-D, streptozotocin diabetic rats; GS, glomerulosclerosis; PG, prostaglandin. creased urinary albumin excretion [6-8] in diabetic animals.

Most of these observations have been made in short-term type 1 streptozotocin diabetic rats (SZTD). The purpose of the present study was to evaluate the effect of long-term supplementation of myo-inositol in the Cohen diabetic rat (type 2) on the development of pathological changes and $\mathrm{Na}^{+}-\mathrm{K}^{+}$-ATPase activity in the kidneys.

\section{Materials and methods}

Animals. The Cohen diabetic rat shares essential features with human non-insulin-dependent diabetes such as genetic and environmental disposition [9], an early phase of hyperinsulinaemia, and insulin resistance, followed by hypoinsulinaemia [10], a decreased number and sensitivity of insulin receptors 
Table 1. Clinical and biochemical characteristics of Cohen diabetic rats supplemented with myo-inositol (group I)

\begin{tabular}{|c|c|c|c|c|c|c|c|c|c|c|c|}
\hline \multirow[t]{2}{*}{ No } & \multirow{2}{*}{$\begin{array}{l}\text { Pathol- } \\
\text { ogy } \\
\text { No }\end{array}$} & \multirow{2}{*}{$\begin{array}{l}\text { Body } \\
\text { weight } \\
\text { (g) }\end{array}$} & \multirow{2}{*}{$\begin{array}{l}\text { Blood } \\
\text { glucose } \\
(\mathrm{mmol} / \mathrm{l})\end{array}$} & \multirow{2}{*}{$\begin{array}{l}\text { Creatinine } \\
\text { clearance } \\
\left(\mathrm{ml} \cdot \mathrm{min}^{-1} \cdot 100 \mathrm{~g}\right. \\
\text { body weight) }\end{array}$} & \multirow{2}{*}{$\begin{array}{l}\text { Proteinuria } \\
24 \mathrm{~h} \\
(\mathrm{mg})\end{array}$} & \multirow{2}{*}{$\begin{array}{l}\text { (g) kidney } \\
100 \mathrm{~g} / \mathrm{body} \\
\text { weight }\end{array}$} & \multicolumn{3}{|c|}{$\begin{array}{l}\text { Glomerulo- } \\
\text { sclerosis grade }\end{array}$} & \multicolumn{2}{|c|}{$\begin{array}{l}\mathrm{Na}^{+}-\mathrm{K}^{+}-\mathrm{ATP} \text { TSe } \\
\mathrm{Pi} \cdot \mathrm{mg}_{\text {protein }}{ }^{-1} \cdot \mathrm{h}^{-1}\end{array}$} \\
\hline & & & & & & & $\overline{N^{c}}$ & $2+$ & $3-4+$ & cortex & medulla \\
\hline 2 & 1328 & 294 & 29.4 & 0.245 & 86 & 0.510 & $\mathrm{~N}$ & - & - & & \\
\hline 3 & 1326 & 268 & 19.6 & 0.321 & 113 & 0.642 & - & - & $4+$ & & \\
\hline 4 & 1350 & 360 & 23.6 & 0.166 & 37 & 0.417 & $\mathrm{~N}$ & - & - & & \\
\hline 7 & 1351 & 360 & 20.3 & 0.250 & 30 & 0.416 & - & - & $3+$ & & \\
\hline 8 & 1314 & 360 & 19.2 & 0.580 & 49 & 0.841 & - & - & $3+$ & & \\
\hline 9 & 1313 & 360 & 29.4 & 0.325 & 36 & 0.500 & $\mathrm{~N}$ & - & - & & \\
\hline 10 & 1316 & 335 & 22.7 & 0.382 & 26 & 0.570 & $\mathrm{~N}$ & - & - & 42 & 104 \\
\hline 11 & 1317 & 310 & 23.2 & 0.290 & 12 & 0.484 & $\mathrm{~N}$ & - & - & & \\
\hline 12 & 1318 & 291 & 19.7 & 0.249 & 41 & 0.484 & - & - & $3+$ & & \\
\hline
\end{tabular}

${ }^{\mathrm{a}}$ vs downward line $p<0.05$

${ }^{\mathrm{b}}$ vs diabetic non-supplemented $-\chi^{2}(d f=2)=1.9957$

${ }^{c} \mathrm{~N}=$ Normal (o change)

Table 2. Clinical and biochemical characteristics of Cohen diabetic rats (group II) and the downward, non-diabetic line (group III) Cohen diabetic rats (group II)

\begin{tabular}{|c|c|c|c|c|c|c|c|c|c|c|c|}
\hline \multirow[t]{2}{*}{ No } & \multirow{2}{*}{$\begin{array}{l}\text { Pathol- } \\
\text { ogy } \\
\text { No }\end{array}$} & \multirow{2}{*}{$\begin{array}{l}\text { Body } \\
\text { weight } \\
\text { (g) }\end{array}$} & \multirow{2}{*}{$\begin{array}{l}\text { Blood } \\
\text { glucose } \\
(\mathrm{mmol} / \mathrm{l})\end{array}$} & \multirow{2}{*}{$\begin{array}{l}\text { Creatinine } \\
\text { clearance } \\
\left(\mathrm{ml} \cdot \mathrm{min}^{-1} \cdot 100 \mathrm{~g}\right. \\
\text { body weight })\end{array}$} & \multirow{2}{*}{$\begin{array}{l}\text { Proteinuria } \\
24 \mathrm{~h} \\
(\mathrm{mg})\end{array}$} & \multirow{2}{*}{$\begin{array}{l}\text { (g) kidney/ } \\
100 \text { g body } \\
\text { weight }\end{array}$} & \multicolumn{3}{|c|}{$\begin{array}{l}\text { Glomerulo- } \\
\text { sclerosis grade }\end{array}$} & \multicolumn{2}{|c|}{$\begin{array}{l}\mathrm{Na}^{+}-\mathrm{K}^{+} \text {-ATPase } \\
\left(\mu \mathrm{mol} \mathrm{Pi} \cdot \mathrm{mg} \text { protein }{ }^{-1} / \mathrm{h}^{-1}\right)\end{array}$} \\
\hline & & & & & & & $\overline{N^{c}}$ & $1+$ & $\overline{3-4+}$ & cortex & medulla \\
\hline 2 & 1345 & 294 & 20.6 & 0.058 & 23 & 0.558 & $\mathrm{~N}$ & - & - & & \\
\hline 3 & 1343 & 370 & 30.2 & 0.272 & 28 & 0.354 & $\mathrm{~N}$ & - & - & & \\
\hline 4 & 1329 & 300 & 23.2 & 0.267 & 157 & 0.550 & - & - & $3+$ & & \\
\hline 7 & 1330 & 210 & 20.3 & - & 91 & 0.870 & - & - & $4+$ & & \\
\hline 8 & 1348 & 230 & 24 & 0.102 & 33 & 0.373 & $\mathrm{~N}$ & - & - & & \\
\hline 9 & 1320 & 265 & 28.4 & 0.272 & 41 & 0.562 & - & - & $3+$ & & \\
\hline 10 & 1321 & 365 & 19.7 & 0.250 & 75 & 0.556 & - & - & $3+$ & 72 & 220 \\
\hline 11 & 1323 & 312 & 21.2 & 0.234 & 35 & 0.536 & - & - & $3+$ & & \\
\hline 12 & 1324 & 318 & 20.3 & 0.233 & 57 & 0.541 & - & - & $4+$ & & \\
\hline & & $13^{\mathrm{a}}$ & $0.953^{\mathrm{a}}$ & $0.0291^{\mathrm{a}}$ & $22.78^{\mathrm{a}}$ & 0.379 & & & & & \\
\hline & & & & Downward, & on-diabetic li & ne group III & & & & & \\
\hline \multirow{3}{*}{$1-6$} & $1352-$ & $381 \pm$ & $6.71 \pm$ & $0.92 \pm$ & $11.9 \pm$ & $0.347 \pm$ & $\mathrm{N}$ & - & - & 49 & 127 \\
\hline & 1357 & $14.1^{\mathrm{c}, \mathrm{d}}$ & $0.25^{\mathrm{c}, \mathrm{d}}$ & $0.046^{\mathrm{c}, \mathrm{d}}$ & $2.2^{\mathrm{c}, \mathrm{d}}$ & $0.012^{\mathrm{c}, \mathrm{d}}$ & & & & 77 & 131.7 \\
\hline & & & & & & & & & & $\begin{array}{l}126: 2 \\
=63\end{array}$ & $\begin{array}{l}258.7: 2 \\
=129\end{array}$ \\
\hline
\end{tabular}

${ }^{\mathrm{a}}$ vs downward line $p<0.05$
${ }^{\mathrm{V}}$ vs diabetic supplemented $-\chi^{2}(d f=2)=1.9957$

[11], a metabolic response to hypoglycaemic drugs [12], and renal and retinal complications [13]. The procedure that leads to the development of diabetes in this model has been described in detail elsewhere [9]. Briefly, two lines of this strain were selected from parental "Sabra" rats (Hebrew University albino strain) by feeding a copper-deficient (1.2 parts per million, analysed by atomic absorption, spectrophotometry), sucrose-
${ }^{c}$ vs diabetic non-supplemented $p<0.05 ; \mathrm{N}=$ Normal (o change) ${ }^{\mathrm{d}}$ vs diabetic supplemented $p<0.05$ rich diet (sucrose $72 \%$, vitamin-free casein $18 \%$, butter $4.5 \%$, corn oil $0.5 \%$, salt mixture USP No. II $5 \%$, water- and fat-soluble vitamins). Offspring with abnormal glucose tolerance (upward selection) were brother-sister mated and developed hyperglycaemia, glycosuria and diabetic vascular complications. The downward-selected or so-called resistant line remained normal under the sucrose-rich diet. Diabetic animals 
with spontaneous blood glucose levels over $16.6 \mathrm{mmol} / 1$ were used in this study.

\section{Animal groups}

Group I. (Table 1) Sixteen randomly-selected three-month-old diabetic animals continued to consume the high-sucrose diet which was supplemented with $1 \%$ myo-inositol (Sigma, St. Louis, Mo., USA) for 4 months, up to the age of 7 months.

Group II. (Table 2) Fifteen 3-month-old diabetic animals were fed the high-sucrose diet up to the age of 7 months.

Group III. (Table 2) Six male normal non-diabetic animals of the downward line were fed the animal house stock chow diet up to the age of 7 months.

At the age of 7 months in all groups, the blood glucose, 24-h urinary protein excretion and creatinine clearance were determined. The animals were killed under deep pentobarbitol anesthaesia. The kidneys were removed and the left kidney was weighed, and the weight of the kidney per $100 \mathrm{~g}$ body weight was calculated. Specimens for histological studies were taken.

In six animals of groups I, II and III, kidney specimens were taken for evaluation of $\mathrm{Na}^{+}-\mathrm{K}^{+}$-ATPase activity. In groups 1 and $I$, the kidney specimens of animals numbers $9,10,11$ and 12 , showing low urinary protein excretion $(12-75 \mathrm{mg} / 24 \mathrm{~h})$ and of animals numbers 13 and 14, with high urinary protein excretion (108-344 mg/24 h) were pooled separately for determination of $\mathrm{Na}^{+}-\mathrm{K}^{+}$-ATPase activity.

Preparation of microsomes. Preparation of microsomal ATPase was carried out according to Jorgensen and Skou [14]. The pooled tissues were homogenized in 10 volumes of a medium containing 0.25 sucrose, and $2 \mathrm{mmol} / \mathrm{l}$ EDTA buffered with $5 \mathrm{mmol} / 1$ Tris- $\mathrm{HCl}$ to a $\mathrm{pH}$ of 7.4-7.5. The homogenate was centrifuged at $7,000 \mathrm{~g}$ for $15 \mathrm{~min}$; the supernatant was decanted and the sediment centrifuged at $48,000 \mathrm{~g}$ for $40 \mathrm{~min}$. The pellet was resuspended in an equal volume of the above solution and again homogenized in 10 volumes of desoxycholate $0.1 \%$ containing $2 \mathrm{mmol} / \mathrm{l}$ EDTA and $25 \mathrm{mmol} / 1$ TrisHCL ( $\mathrm{pH} 7.0$ ). After incubation at room temperature for $30 \mathrm{~min}$, the suspension was centrifuged at $25,000 \mathrm{~g}$ for $30 \mathrm{~min}$. The pellet was suspended in the above sucrose-EDTA-Tris. This final suspension was frozen at $-20^{\circ} \mathrm{C}$ overnight and assayed the next day.

Assay of ATPase. ATPase activity was determined by the amount of inorganic phosphate (Pi) released during incubation at $37^{\circ} \mathrm{C}$ in a shaking, thermostatic bath, as previously described [15]. All assays were run in duplicates. The Pi release was studied with and without $\mathrm{K}^{+}$in the medium. The standard incubation medium consisted of: (in $\mathrm{mmol} / \mathrm{l}$ ) $\mathrm{NaCl} 100, \mathrm{KCl}$ $10, \mathrm{MgCl}_{2} 4, \mathrm{ATP} 4$. Enzymatic activity was stopped by the addition of $10 \%$ trichloracetic acid. Pi was determined according to the method of Fiske and Subbarow [16]. Enzymatic protein was assayed according to Lowry et al. [17]. $\mathrm{Na}^{+}-\mathrm{K}^{+}$-ATPase was estimated as the difference of Pi release with and without $\mathrm{K}^{+}$in the medium.

Creatinine clearance. Fluid intake and urine output were measured at 24-h intervals for 2 consecutive days in animals kept separately in metabolic cages. On the third day, blood was taken from the tail. Creatinine in the blood and urine was measured by an automatic picric acid method (Roche, Cobas Mira

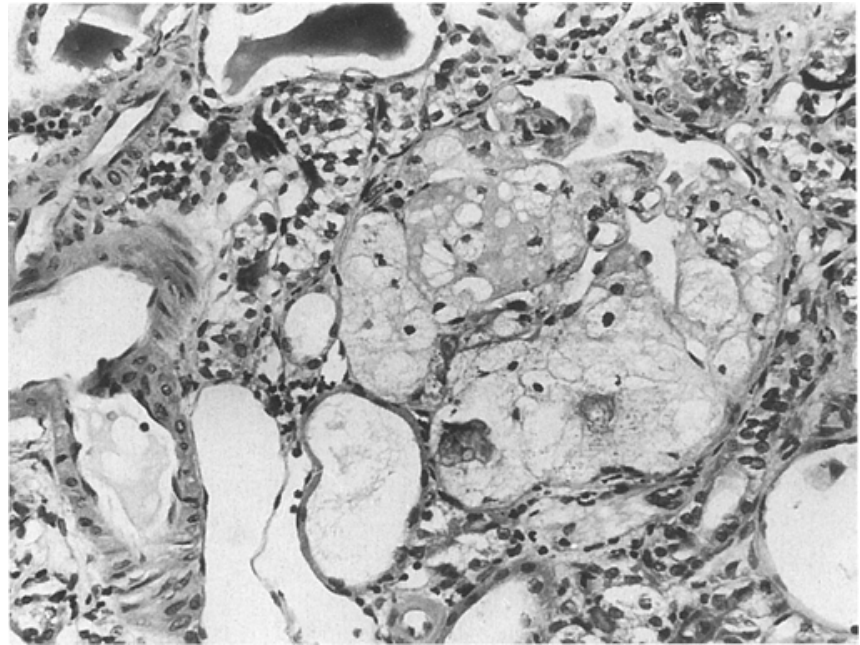

Fig. 1. Histologic section of kidney of diabetic animal with grade IV lesion showing xanthomatous lesions in a glomerulus

Diagnostica, Basel, Switzerland) and evaluated per $100 \mathrm{~g}$ body weight.

Blood glucose. Animals were fasted overnight; the next day food was served at 08.00 , and 10.00 hours a blood sample was taken from the tip of the tail in heparinized test tubes. Blood glucose levels were determined by a SMAC II system (Technion Instrument Corp, New York, N. Y., USA).

Pathological evaluation and grading. Whole transverse sections of both kidneys were evaluated blind by the pathologist (E.R.), and approximately 300 glomeruli were screened in each case. The degree of glomerulosclerosis (GS) was graded according to the number of glomeruli involved (focal or generalized), and the extent of glomerular involvement (segmental or diffuse). The degree of histopathological changes was rated from 0 to $4: 0=$ no change; grade $1=$ focal, $15-30 \%$ of glomeruli segmentally and/or diffusely involved; grade 2 = focal, 30 $50 \%$ of glomeruli segmentally and/or diffusely involved; grade $3=$ generalized, $50-100 \%$ of glomeruli segmentally and/or diffusely involved; grade $4=$ generalized, with secondary tubular atrophy and/or dilatation and mild interstitial fibrosis, with xanthomatous (Fig. 1) and/or lipohyaline glomerular lesions. None of the affected kidneys were found to have Armanni-Ebstein lesions.

\section{Statistical analysis}

Results were expressed as mean \pm SEM. The unpaired Student's $t$-test and the chi-square test were used. Differences were considered significant at $p<0.05$.

\section{Results}

During the experimental period two animals from the treated diabetic group and one animal from the untreated group died in the cage. 


\section{Plasma glucose and body weight}

Blood glucose levels ranged between 19.7 and $30.2 \mathrm{mmol} / \mathrm{l}$, and were not affected by the myo-inositol supplement, $21.9 \pm 0.97 \mathrm{mmol} / \mathrm{l}$ in the treated and $23 \pm 0.95 \mathrm{mmol} / \mathrm{l}$ in the untreated diabetic group.

Body weight was also unaffected by myo-inositol treatment, $332 \pm 10 \mathrm{~g}$ in the treated group vs $300 \pm$ $13 \mathrm{~g}$ in the non-treated diabetic group as compared to $381 \pm 14.1 \mathrm{~g}$ in the non-diabetic-resistant line.

\section{Kidney weight, creatinine clearance and proteinuria}

Kidney weight per $100 \mathrm{~g} /$ body weight was unaffected by myo-inositol treatment, $0.553 \pm 0.032 \mathrm{~g}$ in the treated vs $0.575 \pm 0.379 \mathrm{~g}$ in the untreated diabetic animals. They were both significantly higher than in the non-diabetic controls, at $0.347 \pm 0.012 \mathrm{~g}$.

Creatinine clearance. Although creatinine clearance is not a good measure of glomerular filtration rate (GFR) in diabetic rats, as significant tubular handling of creatinine occurs, it gave an approximate idea of the renal function when compared with the diabetic controls. Thus, it was lower in the diabetic than in the non-diabetic animals and was unaffected by the treatment being $0.303 \pm 0.026 \mathrm{ml} \cdot \mathrm{min}^{-1} \cdot 100 \mathrm{~g}$ body weight $^{-1}$ in the treated, and $0.262 \pm 0.0291$ in the untreated diabetic group as compared to $0.92 \pm 0.046$ in the normal non-diabetic resistant line.

Proteinuria. In the non-diabetic rats (group III) protein excretion was $11.9 \pm 2.2 \mathrm{mg} / 24 \mathrm{~h}$. Proteinuria in the diabetic rats was unaffected by myo-inositol treatment, being $77.4 \pm 22.7 \mathrm{mg} / 24 \mathrm{~h}$ in the untreated diabetic group as compared with $79.1 \pm 22.78$ in the treated diabetic group.

\section{$N a^{+}-K^{+}$-ATPase}

When we compared medullary $\mathrm{Na}^{+}-\mathrm{K}^{+}$-ATPase activity in animals with and without GS as a marker of the disease and pooling the results of animals with high and low protein in each group, we found that in the treated group I (animals numbers 13 and 14 with GS) it was $49 \mu \mathrm{mol} \cdot \mathrm{mg}$ protein ${ }^{-1} \cdot \mathrm{h}^{-1}$ and in animals 9-14 (three with GS) it was 77. In the untreated diabetic group II (animals numbers 9-14, all with GS) it was $146 \mu \mathrm{mol} \cdot \mathrm{mg} \operatorname{protein}^{-1} \cdot \mathbf{h}^{-1}(220+72=292: 2)$. In group III without GS (animals 1-6) it was $129 \mu \mathrm{mol} \cdot \mathrm{mg}$ protein ${ }^{-1} \cdot \mathrm{h}^{-1}(127+132=259: 2)$. In the cortex in the untreated group I (animals 13 and 14) the $\mathrm{Na}^{+}-\mathrm{K}^{+}$-ATPase was 47 and in animals numbers $9-14$ ( 3 with GS) it was $45(47+42=89: 2)$. In the untreated diabetic group II (animals numbers 9-
14 all with GS) it was $61(49+72=124: 2)$ and in the non-diabetic group III it was $63 \mu \mathrm{mol} \cdot \mathrm{mg} \operatorname{protein}^{-1}$. $\mathrm{h}^{-1}(49+77=124: 2)$. It was apparent that in the treated group the medullary and the cortical $\mathrm{Na}^{+}-\mathrm{K}^{+}-\mathrm{AT}$ Pase activity levels were lower, 49 or $77 \mu \mathrm{mol} \cdot \mathrm{mg}$ protein $^{-1} \cdot \mathrm{h}^{-1}$ than 146 found in the untreated diabetics. In the cortex of the treated group it was 47 or $45 \mathrm{vs}$ $61 \mu \mathrm{mol} \cdot \mathrm{mg}$ protein ${ }^{-1} \cdot \mathrm{h}^{-1}$ in the untreated diabetic rats. Although these figures cannot be tested for their statistical significance, they represent a pool of six animals each and the difference in the medullary $\mathrm{Na}^{+}-\mathrm{K}^{+}$-ATPase activity between the treated and untreated diabetic rats is about $50 \%$.

\section{Renal pathology}

In the non-diabetic resistant line, there were no pathological changes in the kidney as previous experience has shown in sucrose-fed resistant animals [19]. In the diabetic animals severe renal pathological changes were observed which remained unaffected by the treatment. Among the kidneys of the 14 treated diabetic animals (group I), seven were grade $3-4^{+}$ GS, one was grade $2^{+}$, while six were normal. Among the kidneys of the untreated diabetic rats (group II) there were nine animals with grade $3-4^{+} \mathrm{GS}$, and five were normal, $\chi^{2}(d f=2)=1,9957$. In all rats with very high urinary protein excretion in both groups I and II the pathological changes were grade $3-4+$, although not all the animals with severe pathological changes had high urinary protein excretion and vice versa.

\section{Discussion}

Hyperglycaemia is an important aetiologic factor in the development of vascular complications in diabetic patients [20-22]. Animal studies have provided direct links between hyperglycaemia and histological changes in the kidney and retina $[10,23]$. The exact mechanism of onset of diabetic complications has not been clarified and multiple genetic, metabolic and vascular factors may be involved.

It has been postulated that lower concentrations of intracellular myo-inositol as a result of sorbitol accumulation may contribute to the pathogenesis of diabetic nephropathy $[1,2]$. This is deducted from short-term studies in streptozotocin diabetic (SZTD) (IDDM) animals showing that early administration of aldose reductase inhibitors reduces the increased GFR $[5,6]$ and partly reduces the increased urinary albumin excretion $[6-8,24]$. The results of the studies on the effect of dietary myo-inositol supplementation on the GFR differ. Goldfarb et al. [25] report a decrease while Cohen et al. [28] did not find a change, although they report a decrease in renal $\mathrm{Na}^{+}-\mathrm{K}^{+}-$ATPase. 
In our study, long-term (4 months) myo-inositol supplementation to the Cohen diabetic (type 2) animals did not reduce the increased renal weight and the urinary protein excretion or affect the reduced creatinine clearance, neither did it improve or reduce the renal pathological changes. This is in contrast to the reported beneficial effect of myo-inositol dietary supplementation on nerve conduction [26] and the disruption of structural neural elements [27]. A possible explanation for these differences may be that in the nerve tissue, contrary to renal tissue, $\mathrm{Na}^{+}$$\mathrm{K}^{+}$-ATPase [28-30] and myo-inositol [29-33] are reduced, whereas in the renal cortex and medulla the $\mathrm{Na}^{+}-\mathrm{K}^{+}$-ATPase is elevated $[15,28,33]$ and the outer medulla is rich in myo-inositol $[28,34,35]$. Also, in nerve tissue vasoconstriction and reduced blood supply occur [36-38] while the kidney shows vasodilatation $[39,40]$ and increased blood flow [41-43]. In the nerve, $\mathrm{Na}^{+}-\mathrm{K}^{+}$-ATPase impairment results in sodium accumulation, which a) selectively blocks nodal depolarization, thereby diminishing composite conduction velocity $[30,44]$, and $b)$ leads to the swelling of cells and disruption of structural elements [27]. In the diabetic kidney there is extensive electrolyte loss resulting from increased glucose diuresis and increased glomerular filtration resulting from vasodilatation caused by renal prostaglandin (PG) formation. The increased renal tubular $\mathrm{Na}^{+}-\mathrm{K}^{+}$-ATPase which causes excessive electrolyte reabsorption [45] may compensate for these physiological changes [46].

The present study emphasizes the difference between the reported beneficial effect of myo-inositol supplementation on the increased GFR in the early stages of SZT-D and the lack of effect of long-term myo-inositol treatment on the development of severe diabetic nephropathy in the Cohen rat. The precise role of increased glomerular pressure in the evolution of diabetic glomerulopathy is uncertain [47]. In rats, severe diabetic nephropathy can occur without an increase in glomerular capillary pressure [ 48 , 49] and in humans [50-52] hyperfiltration does not appear to be a predictor of the development of proteinuria and renal dysfunction. Also, in the rat acute SZT-D causes natriuresis and increased urinary output that precedes the increase in GFR [15]. The enhanced tubular reabsorption of glucose, $\mathrm{Na}^{+}$and water may increase the GFR $[53,54]$. The above studies suggest that: a) the GFR in SZT-D may be modified in a way that is independent of the effect of myoinositol on kidney ATPase; b) that even if the GFR is improved by myo-inositol treatment it does not necessarily prevent the development of nephropathy in diabetes; and c) as stated above increased GFR in diabetes might be the result of increased glucose diuresis and increased PG synthesis [54, 55], which lead to hyperfiltration $[40,41,55]$.

The progression of renal pathological changes in the present study despite the myo-inositol treat- ment, indicates that they may be due to other metabolic and humoral factors resulting from hyperglycaemia, such as: 1) mechanisms other than the aldose reductase pathway, such as altered pyridine nucleotide ratios, which affect other cellular biochemical steps [56]; 2) in diabetes there is increased de novo production of diacylglycerol [57] in the glomeruli [58] and cultured mesangial cells [59] which results in increased protein kinase $\mathrm{C}$ activity which causes enhanced growth of vascular cells [60], increased smooth muscle cell contraction [61], and increased cyclic AMP responses to different hormones in vascular cells [62], and increased PG synthesis by glomeruli and mesangial cells $[54,57]$. Overproduction of PG plays a role in early renal hyperfusion and hyperfiltration [39, 40, 43, 63]; 3) Excessive formation of free radicals [64] which are cytotoxic to vascular endothelial cells [65] and contribute to the progressive deterioration of function in diabetic tissues $[66,67]$. Oxidative modification of LDL is a key step in the formation of foam cells, as such modification is required to allow macrophage receptors to recognize LDL [68]. The analogy between diabetic nephropathy and atherosclerosis has been made previously $[69,70]$. In the present model there is a large number of foam cells in the glomeruli (Fig. 1) with a severe degree of GS, which may be due to the oxidative modification of LDL; [2] in the presence of hyperglycaemia non-enzymatic glycation of proteins occurs, which turn slowly into advanced glycation end products. These accumulate constantly on long-lived vessel wall proteins contributing to the thickening of basement membranes [71]. In our previous study [72] repeated injections of glycated plasma resulted in the development of GS in the Cohen prediabetic rats.

Several biochemical disturbances provoked by hyperglycaemia have been implicated in the development of irreversible structural tissue changes in diabetes. In the SZT-D nerve, myo-inositol supplementation was reported to restore impaired conduction. velocity [26], low $\mathrm{Na}^{+}-\mathrm{K}^{+}$-ATPase and disruption of structural elements [27] in the nerve and reduce the increased GFR and proteinuria of the early changes of SZT-D. In contrast, long-term administration of myo-inositol to the Cohen diabetic rat had no beneficial effect on the development of renal pathological changes although it reduced the elevated renal $\mathrm{Na}^{+}$$\mathrm{K}^{+}$-ATPase activity. These results indicate that the effect of the biochemical disturbances ensuing from hyperglycaemia vary in different diabetic tissues and depend upon local conditions.

Acknowledgement. We thank Professor M. Brezis, Department of Medicine, Hadassah University Hospital, Mount Scopus, for allowing us the use of his Renal Pathophysiology laboratory for the determination of the creatinine clearance. 


\section{References}

1. Winegrad AI (1987) Does a common mechanism induce the diverse complications of diabetes? Diabetes 36: 396-406

2. Greene DA, Lattimer SA, Sima AAF (1987) Sorbitol, phosphoinositides and sodium-potassium ATPase in the pathogenesis of diabetic complications. N Engl J Med 316: 599-606

3. Greene DA (1987) Diabetic complications: nephropathy. Drug Therapy 17: 33-42

4. Greene DA (1988) The pathogenesis and prevention of diabetic neuropathy and nephropathy. Metabolism [Suppl 1] $25-29$

5. Goldfarb S, Ziyadeh FN, Kern EFO, Simmons DA (1991) Effects of polyol-pathway inhibition and dietary myo-inositol on glomerular hemodynamic function in experimental diabetes in rats. Diabetes 40: $465-471$

6. Tilton RG, Chang K, Pugliese G et al. (1989) Prevention of hemodynamic and vascular albumin filtration changes in rats by sorbinil, and aldose reductase inhibitors. Diabetes 37: $1258-1270$

7. Beyer-Mears A, Cruz E, Edelist T, Varagiannis E (1986) Diminished proteinuria in diabetes mellitus by sorbinil and aldose reductase inhibitor. Pharmacology 32: 52-60

8. McCaleb ML, Sredy J, Millen J, Ackerman DM, Dvornik D (1988) Prevention of urinary albumin excretion in 6 month streptozotocin diabetic rats with the aldose reductase inhibitor to restat. Diab Comp 2: 16-18

9. Cohen AM, Teitelbaum A, Saliternik R (1972) Genetics and diet as factors in the development of diabetes mellitus. Metabolism 21: 235-240

10. Cohen AM, Wiegand S, Kaiser S, Federlin K (1990) The insulin response in the Cohen diabetic rat. In: Cohen AM, Rosenmann E (eds) The Cohen diabetic rat. Karger, Basel pp 44-53

11. Madar Z, Teitelbaum A, Miller E, Cohen AM (1984) Genetic differences in insulin receptors in adipocytes of diabetic rats. In: Shafrir E, Renold AE (eds) Lessons from animal diabetes. Libbey, London, pp 111-112

12. Cohen AM, Yanko L, Rosenmann E (1983) Control of blood glucose levels and development of diabetic microangiopathy. Effect of Glibornuride. Isr J Med Sci 19: 311-318

13. Cohen AM, Teitelbaum A, Briller S, Yanko L, Rosenmann E, Shafrir E (1974) Experimental models of diabetes. In: Sippel HL, McNutt KW (eds) Sugars in nutrition. Academic Press, New York, pp 484-511

14. Jorgensen PL, Skou JC (1969) Preparation of highly active $\mathrm{Na}^{+}-\mathrm{K}^{+}$-ATPase from the outer medulla of rabbit kidney. Biochem Biophys Res Commun 37: 39-46

15. Wald H, Scherzer P, Popovtzer M (1986) Enhanced renal tubular ouabain-sensitive ATPase in streptozotocin diabetes mellitus. Am J Physiol 251: F164-F170

16. Fiske CH, Subbarow Y (1925) The calorimetric determination of phosphorus. J Biol Chem 66: 375-400

17. Lowry OH, Rosebrough NJ, Farr AL, Randall RJ (1951) Protein measurement with the Folin-phenol reagent. J Biol Chem 193: 265-275

18. Wald H, Popovtzer MM (1984) The effect of streptozotocin-induced diabetes mellitus on urinary excretion of sodium and renal $\mathrm{Na}^{+}-\mathrm{K}^{+}$-ATPase activity. Pfluger Arch 401: 97-100

19. Cohen AM, Teitelbaum A, Briller S, Rosenmann E, Yanko L, Shafrir E (1974) Role of diet and genetics in the development of angiopathy in diabetes. Hormone and Metabolic Research [Suppl] 4: 118-124

20. Pirart J (1978) Diabete et complications degeneratives: presentation d'une etude prospective portant sur 4400 cas observes entre 1947 et 1973 (deuxieme partie). Diabete Metab 3: 173-182

21. The DCCT Research Group (1988) Are continuing studies of metabolic control and microvascular complications in insulin-dependent diabetes mellitus justified? N Engl J Med 318: $246-250$

22. Stearns S, Schlesinger MJ, Rudy A (1947) Incidence and clinical significance of coronary artery disease in diabetes mellitus. Arch Int Med 19: 463-497

23. Kern TS, Engerman RL (1990) Arrest of glomerulopathy in diabetic dogs by improved glycaemic control. Diabetologia 33: $522-525$

24. Chang WP, Dimitriadis E, Allen T, Dunlop ME, Cooper M, Larkins RG (1991) The effect of aldose reductase inhibitors on glomerular prostaglandin production and urinary albumin excretion in experimental diabetes mellitus. Diabetologia 34: 225-231

25. Goldfarb S, Simmons DA, Kern EF (1986) Amelioration of glomerular hyperfiltration in acute experimental diabetes mellitus by dietary myo-inositol supplementation and aldose reductase inhibition. Trans Assoc Am Phys 99: 6772

26. Greene DA, Dejesus PU, Winegrad AI (1975) Effects of insulin and dietary myo-inositol on impaired peripheral motor nerve conduction velocity in acute streptozotocin diabetes. J Clin Invest 55: 1326-1336

27. Sima AAF, Lattimer SA, Yagihashi S, Greene DA (1986) "Axioglial dysfunction", a novel structural lesion that accounts for poorly reversible slowing of nerve conduction in the spontaneously diabetic BB rat. $\mathbf{J}$ Clin Invest 77 : 474-484

28. Cohen RA, MacGregor LC, Spokes KC, Silva P, Epstein FH (1990) Effect of myo-inositol on renal $\mathrm{Na}^{+}-\mathrm{K}^{+}-\mathrm{ATP}$ ase in experimental diabetes. Metabolism 39: 1026-1032

29. Das PK, Bray GM, Aguayao AJ, Rasminsky M (1976) Diminished ouabain sensitive, sodium-potassium ATPase activity in sciatic nerves of rats with streptozotocin-induced diabetes. Exp Neurol 53: 285-288

30. Greene DA, Yagihashi S, Lattimer SA, Sima AAF (1984) Nerve $\mathrm{Na}^{+}-\mathrm{K}^{+}-$ATPase, conduction and myo-inositol in the insulin-deficient BB rat. Am J Physiol 247: E534-E539

31. Greene DA, Mackway AM (1986) Decreased myo-inoitol content and $\mathrm{Na}^{+}-\mathrm{K}^{+}-\mathrm{ATPase}$ activity in superior cervical ganglion of SZT diabetic rats and prevention by aldose reductase inhibition. Diabetes 35: 1106-1108

32. Mayhew JA, Gillon KRW, Hawthorne JN (1983) Free and lipid inositol, sorbitol and sugars in sciatic nerve obtained post-mortem from diabetic patients and control subjects. Diabetologia 24: 13-15

33. Wald H, Scherzer P, Rasch R, Popovtzer MM (1993) Renal tubular $\mathrm{Na}^{+}-\mathrm{K}^{+}$-ATPase in diabetes mellitus; relationship to metabolic abnormality. Am J Physiol 265 (Endocrinol Metab 28) E96-E101

34. Cohen MAH, Hruska KA, Daughaday WH (1982) Free myo-inositol in canine kidneys: selective concentration in the renal medulla. Proc Soc Exp Biol Med 169: 380-385

35. Dawson RMC, Freinkel N (1961) The distribution of free mesoinositol in mammalian tissues including some observations on the lactating rat. Biochem J 78: 606-610

36. Hotta N, Kakuta H, Fukasawa H et al. (1992) Effect of niceritrol on streptozotocin-induced diabetic neuropathy in rats. Diabetes 41: 587-591

37. Low PA, Tuck RR, Dyck PJ, Schmelzer JD, Yao JK (1984) Prevention of some electrophysiologic and biochemical abnormalities with oxygen supplementation in experimental diabetic neuropathy. Proc Natl Acad Sci USA 81: 6894 6898 
38. Nigishi H, Hironobu K, Hideo F et al. (1992) Effect of niceritrol on streptozotocin-induced diabetic neuropathy in rats. Diabetes 41: 587-591

39. Kasiske BL, O'Donnell MP, Keane WF (1985) Glucose-induced increase in renal hemodynamic function. Possible modulation by renal prostaglandin. Diabetes 34: 360-364

40. Esmatjes E, Fernandez MR, Halperin I et al. (1985) Renal hemodynamic abnormalities in patients with short term insulin-dependent diabetes mellitus: role of renal prostaglandins. J Clin Endocrinol Metab 60: 1231-1236

41. Mogensen CE (1971) Glomerular filtration rate and renal plasma flow in short-term and long-term juvenile diabetes mellitus. Scand J Clin Lab Met 28: 91-100

42. Christiansen JS, Gammelgaard J, Frandsen M, Parving HH (1981) Increased kidney size, glomerular filtration rate and renal plasma flow in short-term insulin-dependent diabetics. Diabetologia 20: 451-456

43. Jensen PK, Christiansen JS, Steven K, Parving H-H (1981) Renal function in streptozotocin-diabetic rats. Diabetologia 21: 409-414

44. Brismar T, Sima AAF (1981) Changes in nodal function in nerve fibers of the spontaneously diabetic BB-Wistar Rat. Potential clamp analysis. Acta Physiol Scand 113: 499-506

45. Katz AL, Epstein FH (1967) The role of sodium potassium activated adenosine triphosphate in the reabsorption of sodium by the kidney. J Clin Invest 46: 1999-2011

46. Wald H, Epstein EH, Popovtzer MM (1983) Effect of chronic salt loading on renal $\mathrm{Na}^{+}-\mathrm{K}^{+}$-ATPase activity in the rat. Proc Soc Exp Med 177: 291-296

47. Castellino P, Shohat J, DeFronzo RA (1990) Hyperfiltration and diabetic nephropathy: is it the beginning? or is it the end? Sem Nephrol 10: 228-241

48. Hostetter TH, Troy JL, Brenner BM (1981) Glomerular hemodynamics in experimental diabetes mellitus. Kidney Int 19: 410-415

49. Michels LD, O'Donnel MP, Keane WF (1987) Glomerular hemodynamics and structural correlation in long-term experimental diabetic rats. J Lab Clin Med. 103: 840-847

50. Mogensen CE, Christensen CK (1984) Predicting diabetic nephropathy in insulin-dependent patients. N Engl J Med 311: 89-93

51. Viberti GC, Jarret RJ, Weisman MJ (1984) Predicting diabetic nephropathy. N Engl J Med 311: 1256-1257

52. Lervang $\mathrm{H}-\mathrm{H}$, Jensen S, Brøchner-Mortensen J, Ditzel J (1988) Early glomerular hyperfiltration and the development of late nephropathy in type 1 (insulin-dependent) diabetes mellitus. Diabetologia 31: 723-729

53. Schambelan M, Blake S, Sraer J, Bens M, Nivez MP, Wabbe F (1985) Increased prostaglandin production by glomeruli isolated from rats with streptozotocin-induced diabetes mellitus. J Clin Invest 75: 404-412

54. Ditzel J, Junker K (1972) Abnormal glomerular filtration rate, renal plasma flow, and renal protein excretion in recent and short-term diabetics. BMJ 2: 13-19

55. Kreisberg JI, Patel PY (1983) The effects of insulin, glucose and diabetes on prostaglandin production by rat kidney glomeruli and cultured glomerular mesangial cells. Prostaglandins Leukotrienes Med 11: 431-442
56. Travis SE, Morrison AD, Clements RS Jr, Winegrad AI, Oski FA (1971) Metabolic alterations in the human erythrocyte produced by increase in glucose concentration: the role of the polyol pathway. Clin Invest 50: 2104-2112

57. Lee T-S, Saltsman A, Ohashi H, King GL (1989) Activation of protein kinase $\mathrm{C}$ by elevation of glucose concentration: Proposal for a mechanism in the development of diabetic vascular complications. Proc Natl Acad Sci USA 86: 51415145

58. Craven PA, Davidson CM, De Rubertis FR (1990) Increase in diaglycerol mass in isolated glomeruli by glucose from de novo synthesis of glycerolipids. Diabetes 39:667-674

59. Larkins RG, Dunlop ME (1991) Prostaglandins, polyols and mesangial cell function in experimental diabetes. In: Rifkin H, Calwel JA, Taylor SI (eds) Diabetes. Excerpta Medica, Amsterdam, pp 180-183

60. Kariya K, Kawahara Y, Tsuda T, Fukuzaki H, Takai Y (1987) Possible involvement of protein kinase C in platelet-derived growth factor stimulated DNA synthesis in vascular smooth muscle cells. Atherosclerosis 63: 251-255

61. Caramelo C, Okada K, Tsai P, Schrier RW (1989) Phorbol esters and protein kinase $C$ in vascular smooth muscle contraction. Am J Physiol 253: H1365-H1371

62. Limas CJ, Limas C (1985) Phorbol ester- and diaglycerolmediated desensitization of cardiac beta-adregenic receptors. Circ Res 57: 443-449

63. Craven PA, Caines MA, DeRubertis FR (1987) Sequential alterations in glomerular prostaglandin and thromboxane synthesis in diabetic rats: relationship to the hyperfiltration of early diabetes. Metabolism 36: 95-103

64. Wolff SP, Dean RT (1987) Glucose autoxidation and protein modification: the potential role of autoxidative glycosylation in diabetes. Biochem J 245: 243-250

65. Morel DW, Chisolm G (1989) Antioxidant treatment of diabetic rats inhibits lipoprotein oxidation and cytotoxicity. $\mathbf{J}$ Lipid Res 30: 1827-1830

66. Baynes JW (1991) Role of oxidative stress in the development of the complications in diabetes. Diabetes 40: 405-412

67. Barnett PA, Gonzalez RG, Chylack LT, Chen H-M (1986) The effect of oxidation on sorbitol pathway kinetics. Diabetes 35: 426-432

68. Steinberg D, Parthasarathy S, Carew TE, Khoo JC, Witztum JL (1989) Beyond cholesterol modifications of lowdensity lipoprotein that increase its atherogenicity. $\mathrm{N}$ Engl J Med 320: 915-923

69. Diamond JR (1991) Analogous pathobiologic mechanisms in glomerulosclerosis and atherosclerosis. Kidney Int [Suppl 31] S29-S34

70. Lyons TJ (1991) Oxidized low density lipoproteins - a role in the pathogenesis of atherosclerosis in diabetes. Diabet Med 8: 411-419

71. Brownlee M, Cerami A, Valassara H (1988) Advanced glycosylation end products in tissue and the biochemical basis of diabetic complications. N Engl J Med 318: 1315--1321

72. Cohen AM, Rosenmann E (1987) Glomerulosclerosis induced by glycosylated plasma in Cohen prediabetic rat. Diabetes 96: [Suppl 1] 207A (Abstract) 